\title{
Ensino Superior
}

\section{Undergraduate study}

\author{
Steiner, J.E., Malnic, G. (Orgs.) Ensino Superior: conceito e dinâmica. \\ São Paulo: EDUSP, 356 p.
}

O ensino superior é um fator importante no desenvolvimento e na autonomia científica e tecnológica dos países, sendo condição básica para trocas efetivas. O livro em tela enfoca o ensino superior tendo por contexto a realidade vivenciada no Brasil e além do Prefácio assinados pelos organizadores, foi composto por 17 textos. No Prefácio os organizadores explicitam que os trabalhos aglutinados na obra enfocam o tríplice desafio da universidade: preservação dos valores acadêmicos tradicionais, atendimento às demandas da sociedade e desbravar novos meios e caminhos.

O primeiro texto é da lavra de Chaimovich e o foco de sua atenção são os desafios do ensino superior no Brasil. É uma apresentação dos vários discursos seguintes, os quais expõem aspectos dos referidos desafios.

A Universidade de São Paulo é enfocada por Schwarzman que retoma os ideais vigentes em sua criação - ter qualidade comparável às melhores do mundo - e a situação atual, suas incertezas e contextos diversificados. No Brasil, mesmo após as iniciativas de inclusão do governo Lula, menos de $10 \%$ da população de 18 a 24 anos está na universidade (FHC queria $30 \%$, chegou a 19\%). Há muito por fazer. Nos países em que a inclusão igualitária já foi superada a preocupação é com a diferenciação da qualidade o que é essencial para ter classe internacional, única maneira efetiva de lidar com a globalização.

Brito trata da relação pesquisa-universidade tendo destacado por sub-temas: a Universidade como local do conhecimento, liberdade acadêmica e autonomia universitária; natureza da pesquisa; financiamento da pesquisa e perspectivas para a universidade brasileira. A maioria dos recursos de pesquisa $(66 \%)$ são fornecidos pelo governo, $20 \%$ pelas Universidades, $7 \%$ por empresas e $7 \%$ por outros.

Marcovitch discute as eleições universitárias apresentando inicialmente um referencial internacional para em seguida enfocar a situação brasileira. Tem ligação com o tema seguinte, isto é o texto de Durham sobre a autonomia universitária, para a qual há consenso quanto a sua necessidade, mas são para caminhar na direção desejada. Apoia suas análises em uma perspectiva histórica do que ocorreu ao longo dos séculos em outros países até caracterizar a situação brasileira envolvendo tema tão complexo e a necessidade de reforma para alcançar esta meta. Ranieri ao dar continuidade a autonomia de educação superior retoma seus aspectos conceituais e jurídicos. A concessão legal de autonomia ao ensino superior vem desde 1834, tendo sido muito restrita ao longo dos dois séculos precedentes, com ligeira melhoria no final do século passado, mas ainda constitui muito do que é denominado "mitologia jurídica" quando de fato deveria ser um bem jurídico. Lobo e Silva Filho, retoma a questão da autonomia das universidades enfocando as de natureza pública, com ênfase nas paulistas mostrando que elas melhoram quando lhes é concedida autonomia,. Para tanto são necessárias: autonomia real, autonomia administrativa, compromisso de gestão, compromisso de orçamento mínimo, compromisso social, compromisso com a produtividade, governabilidade, controle do Estado e transparência.

Barreto enfoca o futuro da pós-graduação brasileira tendo por contexto sua história. Apresenta dados atuais. O Brasil cresceu em vários aspectos como número de formandos, taxa de doutores na população, número de publicações, porém, em ritmo bem mais lento que outros países emergentes, pretenden- 
do em 2010 estar produzindo na proporção que eles o fazem há décadas. Velloso dá continuidade ao estudo da pós-graduação enfocando a inserção dos egressos no mercado de trabalho tendo em vista a formação aqui e no exterior, tendo por base pesquisas em que a CAPES estava interessada. A maioria dos doutores e mestres no Brasil ainda é empregada pelas Universidades, sendo que parte dos doutores tanto de áreas básicas, tecnológicas como profissionais estão envolvidos com pesquisa, além de atribuírem importância à esta formação em pesquisa.

Castro apresenta uma rica reflexão sobre o ensino de massa na universidade sem perda de qualidade viabilizando a necessária expansão, que deve ser feita atendendo aos novos conhecimentos e tecnologias e com professores competentes. Ainda em relação à massificação segue o texto do Schwartzman sobre o financiamento, valendo lembrar que a maioria das instituições são particulares e são elas que abrigam a grande maioria dos alunos. Usualmente o ensino superior tem recebido a maior parte da verba governamental, mas o total das mesmas não tem crescido, de modo que a carência é grande. As agências de fomento tem sido uma válvula para melhoria do quadro, mas esta e outras tentativas não foram suficientes. A forma de gestão das IES estatais reduzem-nas a instituições ineficientes e onde ocorre desperdício. $O$ financiamento para os alunos é ainda insuficiente e há necessidade de revisões das leis.

O texto de Silva - Universidade: a idéia e a história - chama a atenção do leitor para outras questões. Retoma a origem da idéia de Universidade, sua vinculação com a noção de progresso até a vivência universitária atual que não se desvincula do passado mas que requer adaptação com as quais pode se perder aspectos relevantes. Em consonância com as reminiscências vem o texto de Souza relembrando as origens da Universidade de São Paulo, faz uma narrativa de sua vivência pessoal no Colégio Universitário Anexo à USP e na Faculdade de Filosofia, aponta as tensões e contradições, as influências políticas, o fluxo das mulheres e as transformações culturais que ensejou.

Malnic traz o leitor para o presente em busca de delinear o futuro da universidade pública, responsá- vel pela grande maioria da produção nacional que é também produzida principalmente por doutores formados no Brasil (89,2\%). Destaca a importância e a necessidade da pesquisa, de maior apoio às estatais, de melhoria da carreira, de cuidados com a pós-graduação. Conclui "a existência de pesquisa é uma condição sine qua non para formar profissionais eficientes e capazes de criar inovação científica, cultural e tecnológica, e seria um retrocesso gigantesco por a perder tudo que foi feito até hoje” (p. 308). As avaliações do ensino superior podem influir nos encaminhamentos futuros mas elas tem limitações e problemas como aponta Helene em seu texto. A taxa de analfabetismo no Brasil entre as pessoas de 15 a 24 anos (7,5\%) quando comparada aos países da América Latina só não é pior que a do Peru $(8,7 \%)$ sem se considerar a qualidade. De fato o censo de educação básica brasileira mostrou correlação entre 0 aumento dos indicadores quantitativos e a piora do desempenho dos alunos do ensino público. O exame nacional de ensino médio também não é melhor, isto se reflete na avaliação das IES. Há muito por aperfeiçoar nas avaliações sendo especialmente necessário discutir a utilidade da mesma já que não há um empenho correspondente para corrigir os problemas detectados. Dando continuidade ao tema, Gatti discute a avaliação institucional sendo seu referencial o proposto pelos modelos: descritivo, descritivo-analíticos, reflexivos interpretativos e reflexivos participantes. Subjacente às comparações usualmente feitas nas avaliações está a classificação das IES, tema tratado por Steiner que começa por enfocar a motivação, as razões para avaliar. Apresenta a classificação brasileira e a distribuição e tece algumas comparações com os Estados Unidos da América.

Um Apêndice apresenta uma série de tabelas úteis para dar uma visão geral do ensino superior no Brasil (2003): formação por nível nas universidades com dados muito úteis para se ter uma visão geral do ensino superior no Brasil. Trata-se de obra de leitura imprescindível para quantos se ocupam, de alguma forma, com o ensino superior no País.

Geraldina Porto Witter Universidade Camilo Castelo Branco 